with IFN- $\gamma$ before onset of clinical disease (6-8 wk of age) seems to have a salutary effect; however, treatment after onset (12-18 wk of age) worsens disease activity ${ }^{9}$. In the current study, immunotherapy was administered around 11 weeks of age during emergence of clinical disease when IFN- $\gamma$ levels were presumably just rising. Thus, there may be a window during which anti-CD137 immunotherapy can exert optimal therapeutic influence. Notably, in human lupus, activated $\mathrm{T}$ cells produce meager amounts of IFN- $\gamma$. Therefore, it seems possible that anti-CD137 immunotherapy could boost IFN- $\gamma$ production at any stage of disease in people.

The experiments also revealed a mechanism for the marked decline in total IgG and anti-DNA levels with antibody treatment: B-cell apoptosis and depletion of $\mathrm{CD}^{+} \mathrm{T}$ cells. The treated mice were still able to mount a $\mathrm{T}$ cell-dependent humoral response against exogenous antigens, suggesting that helper function for these antigens was retained. By contrast, depletion of $\mathrm{CD}^{+} \mathrm{T}$ helper cells may have disproportionately diminished a helper effect specific for the autoantigen driving the anti-DNA response, thereby restoring anti-DNA B-cell anergy ${ }^{10}$. Whether older animals with established disease will respond comparably to antiCD137 immunotherapy remains to be determined.

The goal of drug discovery for autoimmune diseases is to target processes specific to the immune system in order to arrest disease progression and restore physiological immune responses without major side effects ${ }^{11}$. Currently, several novel therapies for lupus are in clinical trials, including monoclonal antibodies and a B-cell toleragen. If further animal studies of anti-CD137 immunotherapy show as much promise as this study and a fully humanized monoclonal antibody can be developed, then anti-CD137 should progress to phase 1 clinical trials.

1. Sun, Y. et al. Therapeutic treatment of a spontaneous autoimmune disease with an agonistic monoclonal antibody against a costimulatory molecule. Nature Med. 8, 1405-1413 (2002).

2. Shlomchik, M.J., Craft, J.E. \& Mamula, M.J. From $T$ to $B$ and back again: Positive feedback in systemic autoimmune disease. Nature Rev. Immunol. 1, 147-153 (2001).

3. Kammer, G.M., Perl, A., Richardson, B.C. \& Tsokos, G.C. Abnormal T cell signal transduction in systemic lupus erythematosus. Arthritis Rheum. 46, 1139-1154 (2002).

4. Oates, J.C. \& Gilkeson, G.S. Mediators of injury in lupus nephritis. Curr. Opin. Rheumatol. 14, 498-503 (2002).

5. Sica, G. \& Chen, L. Modulation of the immune response through 4-1BB. Adv. Exp. Med. Biol. 465, 355-362 (2000)

6. Ye, Z. et al. Gene therapy for cancer using singlechain Fv fragments specific for 4-1BB. Nature Med. 8, 343-348 (2002).

7. Halstead, E.S., Mueller, Y.M., Altman, J.D. \& Katskikis, P.D. In vivo stimulation of CD137 broadens primary antiviral $\mathrm{CD} 8^{+} \mathrm{T}$ cell responses. Nature Immunol. 3, 536-541 (2002).

8. Balomenos, D., Rumold, R. \& Theofilopoulos, A.N. Interferon- $\gamma$ is required for lupus-like disease and lymphoaccumulation in MRL-Ipr mice. /. Clin. Invest. 101, 364-371 (1998).

9. Nicoletti, F. et al. Dichotomic effects of IFN- $\gamma$ on the development of systemic lupus erythematosus-like syndrome in MRL-Ipr/Ipr mice. Eur. I. Immunol. 30, 438-447 (2000).

10. Seo, S., Mandik-Nayak, L. \& Erikson, J. B cell anergy and systemic lupus erythematosus. Curr. Dir. Autoimmun. 6, 1-20 (2003).

11. Gescuk, B.D. \& Davis, J.C. Jr. Novel therapeutic agents for systemic lupus erythematosus. Curr. Opin. Rheumatol. 14, 515-521 (2002).

Section on Rheumatology and Clinical Immunology

Department of Internal Medicine and

Department of Microbiology and Immunology

Wake Forest University Health Sciences

Winston-Salem, North Carolina, USA

Email:gmkammer@wfubmc.edu

\title{
Big-boned and skinny
}

Beta-blockers can reverse the effects of osteoporosis-that's the surprising conclusion of a study by Shu Takeda, Florent Elefteriou and colleagues in the November 1 Cell. On the right is a cross-section of a vertebra from a mouse treated with beta-blockers, and on the left, one from a non-treated mouse. Beta-blockers increase the bone mass (black) in the vertebrae and other bones. These drugs also replace bone in mice that have had their ovaries removed to mimic the bone weakness that occurs commonly in post-
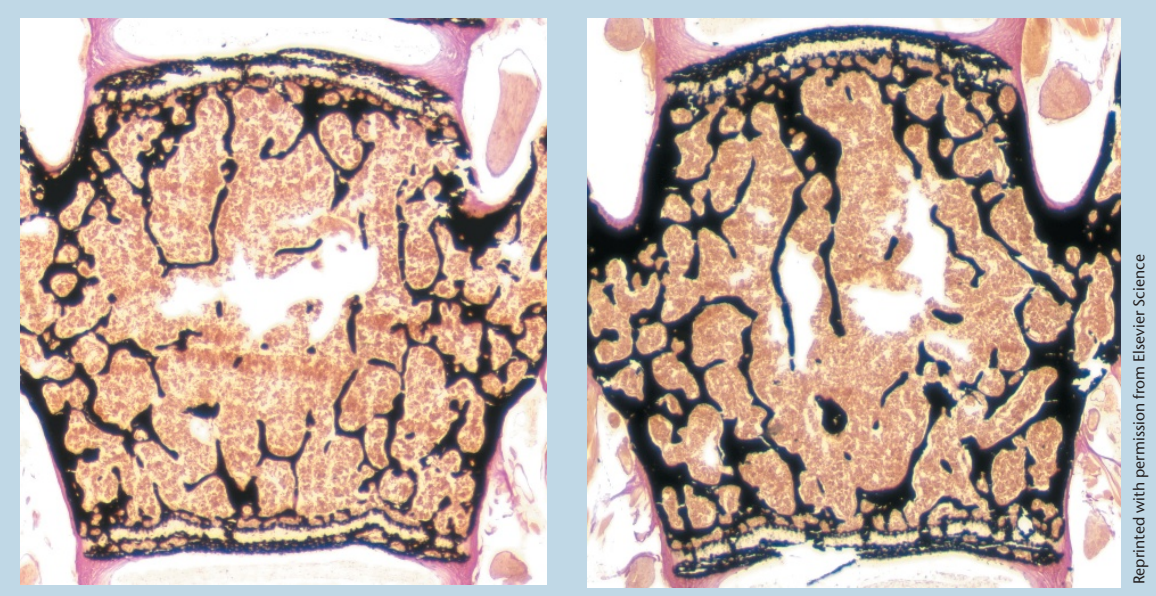
menopausal women.

The investigators launched their research with an analysis of the weight-regulating hormone leptin. They had known from previous studies that mice lacking leptin are extremely obese-but they also have greater bone mass than normal mice. This observation has its parallel in people, as obese individuals rarely suffer from osteoporosis. The authors found that leptin's effects on weight are regulated independently of its effects on bone mass. A division of the sympathetic nervous system receives leptin signals in the brain and transmits them to bone-forming cells, or osteoblasts, throughout the body.

Different types of adrenergic receptors mediate the functions of the sympathetic nervous system, which include timing the heart beat and breathing. Indeed, $\beta 2$-adrenergic receptors stud the cells in heart muscle, and $\beta 2$-adrenergic agonists-beta-blockers-are commonly prescribed to regulate blood pressure. The authors found that osteoblasts also expressed $\beta 2$-adrenergic receptors and responded to beta-blocker treatment. If the approach works in people, it could offer hope to individuals afflicted with osteoporosis - which number about ten million in the United States alone. Currently prescribed drugs for osteoporosis arrest bone destruction, but cannot increase bone formation and reverse the effects of bone damage.

CharlotTe SCHUberT 